\title{
ESTIMATION OF AN EXTENDED SAM WITH HOUSEHOLD PRODUCTION FOR SPAIN 1995*
}

\author{
Ezequiel Uriel, Javier Ferri y $\mathbf{M}^{\mathrm{a}}$ Luisa Moltón
}

WP-EC 2005-08

Corresponding author: Ezequiel Uriel, Instituto Valenciano de Investigaciones Económicas, C/ Guardia Civil, 22, Esc. 2, Primero, 46020 Valencia, Spain, Phone: 34-96-319 00 50, Fax: 34-9631900 55, E-mail: ezequiel.uriel@ivie.es

Editor: Instituto Valenciano de Investigaciones Económicas, S.A.

Primera Edición Abril 2005

Depósito Legal: V-2043-2005

IVIE working papers offer in advance the results of economic research under way in order to encourage a discussion process before sending them to scientific journals for their final publication.

\footnotetext{
* Ezequiel Uriel acknowledges financial support by CICYT grant SEC2002-03375 and CTIDIB/2002/209. Javier Ferri is also grateful to the CICYT grant SEC2002-00266.

** E. Uriel: Ivie y Universitat de València; J. Ferri y M.L. Moltó: Universitat de València.
} 


\title{
ESTIMATION OF AN EXTENDED SAM WITH HOUSEHOLD PRODUCTION FOR SPAIN 1995
}

\author{
Ezequiel Uriel, Javier Ferri and María Luisa Moltó
}

\begin{abstract}
This paper implements the conceptual framework sketched by Pyatt (1990) to construct an extended Social Accounting Matrix for Spain in 1995 (ESAM-95) to consider, in addition to the market economy, the production of services provided by households through unpaid work. In doing so, the ESAM-95 integrates the accounts related to market activities (ESA accounts) with non-market activities (non-ESA accounts) in a consistent way. Additional classifications are introduced in both ESA and non-ESA accounts in order to disaggregate the institutional accounts by household type and those of production factors by educational level and gender. The extended SAM is useful to calibrate CGE models in which the distribution of time between paid and unpaid work is a relevant variable.
\end{abstract}

Key words: Social accounting matrix; use of time; household production JEL codes: C80, C68, E01

\section{RESUMEN}

Este trabajo desarrolla la estructura conceptual diseñada por Pyatt (1990) para ampliar la Matriz de Contabilidad Social para 1995 en España (MCSA-95) con el fin de considerar, además de la economía de mercado, la producción de servicios provista por los hogares mediante el trabajo no retribuido. Así pues, en el MCSA-95 se integran, de una manera uniforme, las cuentas relacionadas con actividades de mercado (cuentas SEC) con las de no-mercado (cuentas no-SEC). Se introducen clasificaciones adicionales tanto en las cuentas SEC como no-SEC a fin de desagregar las cuentas institucionales por tipo de hogar y las de factores de producción por sexo y nivel educativo. La Matriz de Contabilidad de Social Ampliada es útil para calibrar los modelos de equilibrio general computable en los que la distribución del tiempo entre el trabajo retribuido y no retribuido es una variable relevante.

Palabras clave: Matriz de Contabilidad Social; uso del tiempo; producción de los hogares 


\section{Introduction}

GDP has frequently been put on a par with living standards although it excludes large parts of the economy. Thus, the System of National Accounts 1993 (SNA-93) recognizes that movements in GDP cannot be expected to be good indicators of changes in total welfare unless all other factors influencing welfare remain constant (see the discussion in van de Ven et al., 1999). Household production (HP) for own account is one of these factors. ${ }^{1}$ Households play an important role in the economy not only as consumers but also as producers. However, only a small part of that production goes through the market whereas a substantial amount (mainly services) is produced and consumed at home. The omission of non-market household production in national accounts is problematic because it can distort the true rate of growth of economic activity and comparisons of output across countries.

Not surprisingly then, although the national accounts exclude a large amount of the household production of services for own final use, the SNA-93 suggests the elaboration of an alternative concept of gross domestic product by estimating satellite accounts for household production. "Although personal and domestic services produced for own consumption within households fall outside the boundary of production used in the System, it is nevertheless useful to give further guidance with respect to the treatment of certain kinds of household activities which may be particularly important in some countries" (United Nations et al., 1993, paragraph 6.23). The objective of this paper is precisely that, i.e. to extend the production boundary of the SNA (or the European version, the ESA) to include household production but, instead of estimating satellite accounts, to do so using a social accounting matrix framework. Our work builds on the basis of the conceptual framework developed by Pyatt (1990). Thus, the Extended Social Accounting Matrix for 1995 (ESAM-95) introduced in this paper integrates the portion of household production currently outside the boundaries of the ESA into the market flows of a more conventional social accounting matrix (Pyatt, 1985).

\footnotetext{
${ }^{1}$ Other groups of activities not considered by national accounts are: underground activities, illegal activities or the informal sector (OECD et al., 2002). A classification of household activities can be found in Chadeau \& Roy (1986).

${ }^{2}$ See Holloway et al. (2002) for a recent development.
} 
A social accounting matrix is a matrix representation of transactions in the economic system, with special detail for factors and households. A standard SAM integrates the input-output framework in a complete system, assigning the value added to different factors and distributing the income among different households. Production, income generation and the distribution of income are viewed in a comprehensive way. The extended SAM introduced here keeps the basics of a standard SAM, but also includes a non-market subsystem that mimics the market system while at the same time being related to it. As is recognized in the ESA: "integration of more basic data entails the possibility of more policy issues being monitored and analysed in an interrelated [way].Above all, the linkage of employment and income distribution aspects to more macro-oriented objectives such as NDP growth, balance of payments equilibrium, stable price levels, etc. comes within reach with a SAM" (EUROSTAT, 1995, paragraph 8.152). Given that our matrix offers a complete representation of the circular flow of income for both the ESA and the non-ESA side of the economy, it proves to be a powerful instrument for checking consistency between the observed and the nonobserved economy.

The theory of home production and its main applications have been reviewed by Gronau (1997). The idea of households behaving like enterprises using time, services of capital and intermediate inputs to produce commodities for own consumption goes back to Becker (1965) and has significantly influenced different areas of economic analysis by imposing new restrictions on the general version of the utility maximization problem. In the standard household model, utility depends on market goods consumption and leisure, and leisure is understood as non-market time, so the demand functions are conditioned by market prices and wages. However, allowing for the existence of home production, which is a close but not a perfect substitute of market production (an idea that is already present in Gronau, 1977), the household equilibrium will also be characterized by implicit internal prices that are different to observable market prices. This is an important feature that is missing from the standard household model but is present in the extended SAM, which can thus be used to provide empirical support to models including household production.

Previous examples of extending a SAM to supplement national accounts with economic topics falling outside the market mechanisms can be found in Bos et al. (1994) for R\&D issues, in and de Haan \& Keuning (1996) for environmental accounts. As for household production, previous theoretical attempts to link home production and market production are those of Chadeau \& Roy (1986) and Lützel (1989). A pioneering empirical approach can be found in Jorgenson \& Fraumeni (1989). Also Gronau \& Hammermesh (2003) estimate household commodity production by age and educational 
attainment for the United States and Israel. However, to our knowledge, a social accounting matrix combining market and non-market production has not yet been estimated. The approach most closely resembling a SAM is the I-O table estimated by Landefeld \& McCulla (2000). In relation to this research, the present work constitutes a further step in two directions. First, integrating an I-O table for household production into a more complete representation of economic flows. Second, going more deeply into the details of both institutions (including households) and factors of production, most specifically, labor. However, Landefeld \& McCulla (2000) also estimate time series for the value of household non-market services, whereas we do not.

In the following sections a methodology that naturally fits into a standard SAM is introduced, and we carry out the corresponding estimations for Spain in 1995. The ESAM-95 follows the international tendency to improve social statistics ${ }^{3}$ by taking advantage of recent developments in national accounts, household surveys, and procedures for adjusting data that comes from different sources. ${ }^{4}$ Although the starting point for the design of the ESAM is a standard SAM, the methodology followed in this paper for integrating non-market values into national accounting implies the estimation of unpaid work not only in physical terms, but also in monetary units.

The paper is organized as follows. Section 2 summarizes the main characteristics of the ESAM-95 and Section 3 explains the classification used in the matrix. Section 4 outlines the estimation method for market accounts and Section 5 provides information on how the non-ESA accounts of the ESAM-95 have been estimated. Section 6 presents the values for a complete but aggregated version of the social accounting matrix and, finally, Section 7 concludes.

\section{Outline of the Extended Social Accounting Matrix}

The extended SAM displayed in a schematic way in Table 1 is a balanced square matrix. This means that any input or imputation of an income (in the rows) is always matched by an output or imputation of an outlay (in the columns). The ESAM-95 is composed of different blocks of accounts: current accounts and capital accounts

\footnotetext{
3 Keuning (1998) provides a description of the relationship between national accounts and socioeconomic policies. Two examples of improvements in this sense are the Leadership Group on Social Accounting Matrices (SAM-LEG), which was born under the recommendations of the European Economic Council, and the Siena Group for Social Statistics of the United Nations.

${ }^{4}$ We use the cross entropy method (Robinson et al., 2001).
} 
corresponding to institutional sectors; accounts related to productive factors; accounts for activities; accounts for Commodities I; and accounts for Commodities II. Within each block the accounts are broken down into ESA accounts (market transactions) and non-ESA accounts (non-market flows). The remainder of this section is devoted to the description of the ESAM-95 and the accounting relations appearing in the matrix. First, the production accounts of the ESAM-95 are described. Given that the integration of household production is made within a standard SAM framework, the non-ESA part is looked at separately, using the ESA part as the point of departure.

The cost of ESA production consists of taxes, social security contributions, value added by factors of production and intermediate consumption, all appearing in the columns corresponding to ESA activities. All of them are also disaggregated by sector of activity. The corresponding rows of ESA activities represent the sales of products or the income generated by them across Commodities I, which is represented in the submatrix transforming activities in Commodities I (i.e. "Domestic supplies of commodities I"). Commodities I are used to distribute the production, so the classification for both ESA activities and Commodities I is the same and the largest figures are displayed in the main diagonal of the sub-matrix.

The columns of Commodities I contain the total costs of domestic production and the cost of imports, while the corresponding rows display the total demand for Commodities I, which consists of Commodities II (final demand including gross capital formation), plus intermediate consumption of ESA and non-ESA production, plus exports. The matrix that in this paper is called "Supplies of commodities II" is used for converting Commodities I into Commodities II, which are the relevant goods and services for final consumption. For example, when buying a home, the activity of building and the planning or management are not considered separately. In other words, households acquire goods and services once they have been transformed into consumables and are readily available to consumers and investors.

The columns for Commodities II show the transformation matrix of goods and services to consumable goods. The total supply of goods and services for ESA consumption and investment is obtained by adding the taxes on products. In the rows corresponding to Commodities II the households direct consumption and the gross capital formation of the ESA part are found. Both of them form the demand for consumption and investment.

Moving on to the accounts of the Institutions, the rows corresponding to the Current Accounts are dealt with first. These rows contain the income coming from: 
TABLE 1. Structure of the ESAM-95

\begin{tabular}{|c|c|c|c|c|c|c|c|c|c|c|c|c|c|c|c|}
\hline & & & \multicolumn{4}{|c|}{ Institutions } & \multicolumn{7}{|c|}{ Production } & \multirow{3}{*}{$\begin{array}{l}\text { Rest of the } \\
\text { world }\end{array}$} & \multirow{3}{*}{ Total } \\
\hline & & & \multicolumn{2}{|c|}{ Current } & \multicolumn{2}{|c|}{ Capital } & \multicolumn{2}{|c|}{ Factors } & \multicolumn{2}{|c|}{ Activities } & \multirow[b]{2}{*}{ Commodities I } & \multicolumn{2}{|c|}{ Commodities II } & & \\
\hline & & & $\begin{array}{l}\text { Excluded } \\
\text { household } \\
\text { production }\end{array}$ & $\begin{array}{l}\text { Household } \\
\text { production }\end{array}$ & ESA & Non-ESA & ESA & Non-ESA & ESA & Non-ESA & & ESA & Non-ESA & & \\
\hline \multirow{4}{*}{ 号 } & \multirow{2}{*}{ 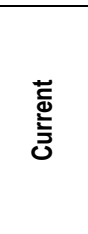 } & $\begin{array}{l}\text { Excluded household } \\
\text { production }\end{array}$ & Current transfers & & & & $\begin{array}{l}\text { ESA factor } \\
\text { incomes }\end{array}$ & & \begin{tabular}{|c|} 
Taxes on \\
production \\
and on \\
interm. inputs \\
\end{tabular} & $\begin{array}{l}\text { Taxes on } \\
\text { products }\end{array}$ & & $\begin{array}{l}\text { Taxes on } \\
\text { products }\end{array}$ & & $\begin{array}{c}\text { Current transfers } \\
\text { from abroad }\end{array}$ & $\begin{array}{l}\text { Total ESA } \\
\text { incomes }\end{array}$ \\
\hline & & Household production & $\begin{array}{c}\text { Endowments for } \\
\text { interm. consump. } \\
\text { and GFCF }\end{array}$ & & & & & $\begin{array}{l}\text { HP factor } \\
\text { incomes }\end{array}$ & & & & & & & $\begin{array}{l}\text { Total HP } \\
\text { incomes }\end{array}$ \\
\hline & \multirow{2}{*}{ 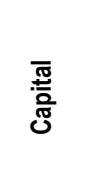 } & ESA & ESA savings & & Capital transfers & & & & & & & & & $\begin{array}{l}\text { Capital transfers } \\
\text { from abroad }\end{array}$ & $\begin{array}{c}\text { Total ESA } \\
\text { capital receipts }\end{array}$ \\
\hline & & Non-ESA & & HP savings & & & & & & & & & & & $\mid \begin{array}{c}\text { Total HP } \\
\text { capital receipts }\end{array}$ \\
\hline \multirow{6}{*}{ 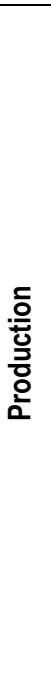 } & 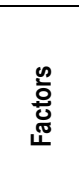 & ESA & & & & & & & $\begin{array}{c}\text { ESA } \\
\text { Value added }\end{array}$ & & & & & $\begin{array}{c}\begin{array}{c}\text { Factor incomes } \\
\text { receipts from } \\
\text { abroad }\end{array} \\
\end{array}$ & $\begin{array}{l}\text { Total ESA } \\
\text { factor } \\
\text { incomes }\end{array}$ \\
\hline & \multirow{2}{*}{ 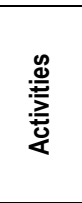 } & ESA & & & & & & & & & \begin{tabular}{|c|} 
Domestic \\
supplies \\
of commodities I
\end{tabular} & & & & $\begin{array}{l}\text { ESA Gross } \\
\text { outputs }\end{array}$ \\
\hline & & Non-ESA & & & & & & & & & & & \begin{tabular}{|c|} 
Supplies \\
of commodities \\
(HP)
\end{tabular} & & $\begin{array}{l}\text { HP Gross } \\
\text { outputs }\end{array}$ \\
\hline & \multicolumn{2}{|r|}{ Commodities I } & & & & & & & \begin{tabular}{|c|} 
ESA \\
Intermediate \\
consumption
\end{tabular} & \begin{tabular}{|c|}
$\mathrm{HP}$ \\
Intermediate \\
consumption
\end{tabular} & & $\begin{array}{c}\text { Supplies } \\
\text { of commodities } \\
\|\end{array}$ & $\begin{array}{c}\text { Demand of } \\
\text { commodities for } \\
\text { HP GFCF }\end{array}$ & Exports & $\begin{array}{c}\text { Total } \\
\text { commodities I } \\
\text { demand }\end{array}$ \\
\hline & \multirow{2}{*}{ 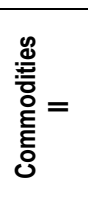 } & ESA & $\begin{array}{c}\text { Resident } \\
\text { consumption } \\
\text { (direct) }\end{array}$ & & ESA GFCF & & & & & & & & & & \begin{tabular}{|c|} 
Total \\
commodities II \\
demand (ESA) \\
\end{tabular} \\
\hline & & Non-ESA & & HP consumption & & HP GFCF & & & & & & & & & \begin{tabular}{|c|} 
Total \\
commodities \\
demand (HP) \\
\end{tabular} \\
\hline & \multicolumn{2}{|c|}{ Rest of the world } & $\begin{array}{c}\text { Resident } \\
\text { consumption and } \\
\text { household } \\
\text { transfers abroad }\end{array}$ & & $\begin{array}{c}\text { Net investment } \\
\text { abroad }\end{array}$ & & $\begin{array}{c}\text { Factor incomes } \\
\text { paid abroad }\end{array}$ & & & & Imports & & & & $\begin{array}{c}\text { Total payments } \\
\text { abroad }\end{array}$ \\
\hline & \multicolumn{2}{|r|}{ Total } & $\begin{array}{l}\text { Total non HP } \\
\text { expenditure }\end{array}$ & $\begin{array}{l}\text { Total HP } \\
\text { expenditure }\end{array}$ & $\begin{array}{l}\text { Total ESA } \\
\text { investment }\end{array}$ & $\begin{array}{c}\text { Total HP } \\
\text { investment }\end{array}$ & $\begin{array}{l}\text { Total factor } \\
\text { payments }\end{array}$ & $\begin{array}{l}\text { Total non-ESA } \\
\text { factor incomes }\end{array}$ & $\begin{array}{l}\text { ESA Gross } \\
\text { inputs }\end{array}$ & $\begin{array}{l}\text { HP Gross } \\
\text { inputs }\end{array}$ & \begin{tabular}{c|} 
Total \\
commodities I \\
supply
\end{tabular} & \begin{tabular}{|c|} 
Total \\
commodities II \\
supply (ESA)
\end{tabular} & $\begin{array}{c}\text { Total } \\
\text { commodities } \\
\text { supply (HP) }\end{array}$ & $\begin{array}{l}\text { Total receipts } \\
\text { from abroad }\end{array}$ & \\
\hline
\end{tabular}


(i) current transfers from the rest of the world; (ii) taxes and social security contributions collected by public administrations; (iii) income from factors, that is, labor income and mixed income received by households, and capital income received mainly by corporations but also by households; and (iv) transfers between institutions. In this last case, among others, the following items are found: transfers from public administrations to households (pensions and subsidies); transfers from corporations to households (distributed profits and interest revenues); transfers from non-profit corporations to households (social assistance) and transfers between households. It also includes "transfers" between the ESA part and the non-ESA part, by household type. They basically consist of the household's endowments for non-ESA intermediate consumption and the purchasing of durables for domestic use.

All transfers to households, both of the ESA part and the non-ESA part, appear in the columns of the accounts of Institutions. The columns of the current account of institutions also include transfers from households to public administration (mainly the personal income tax). The remaining payments refer to ESA savings and consumption. Consumption includes household direct final consumption, government consumption and the non-profit corporation consumption. Finally, the rows of the Capital Account of the institutions capture the savings from the ESA side of the economy, the capital transfers and the borrowing from the rest of the world. Capital transfers, gross fixed capital formation (GFCF) and loans to the rest of the world appear in the corresponding column.

To summarize, ESA production is obtained by adding up the value added of production factors, intermediate consumption of the ESA part and taxes and social security contributions. Total supply consists of domestic production of goods and services plus imported production. This total supply of the ESA side equals the total demand of what is called Commodities I. It has to be noted that total demand for commodities has been rearranged between the ESA and non-ESA part in connection with intermediate consumption, final consumption, and fixed capital formation.

The novelty of the ESAM framework, however, is the non-ESA part. Following the pattern used to describe the ESA side, we will now describe the non-ESA part of the economy. First, the columns of non-ESA activities contain the cost of non-ESA production, classified by function of household production. These costs are made up of taxes, intermediate consumption and the value added of household production. The last component is also disaggregated by gender and educational level. The corresponding rows display a sub-matrix that transforms all activities of household production into non-ESA consumption functions, always within the same function. All the elements of this sub-matrix, except those in the main diagonal, are zero. That is to say, in order for 
households to consume (e.g. education and childcare), a previous transformation of the non-ESA activity that supplies these services into services liable to be consumed is necessary.

As the columns corresponding to Commodities I mostly concern ESA production, the non-ESA production being a very small part of it, the columns of nonESA Commodities II are looked at directly. They contain a sub-matrix transforming activities in products, i.e. "Supplies of commodities (HP)". The total supply of goods of the non-ESA part is obtained by adding to the columns of this sub-matrix the sale of goods for non-ESA gross fixed capital formation, which are basically durable goods. The sum of the rows of Commodities II, in turn, reflects the total demand for non-ESA goods, which is made up of total consumption of household production plus investment.

The rows of the Institutions related to household production include those household expenditures which have been redefined as intermediate consumption or investment ("transfers" from the ESA to non-ESA households), as well as the imputed rent of factors employed in domestic production. The "transfers" referred to above can also be considered as an endowment for intermediate consumption and investment in household production. In other words, a typical household spends part of its income on market goods for direct consumption (e.g. a dress), but another part of the income goes to the purchasing of durables (e.g. a cooker), or intermediate goods that will be used, say, in the elaboration of home meals (e.g. flour). Thus, the total income required to buy both intermediate goods and durables comes from the transfers that ESA institutions pay to non-ESA institutions. In the second block of columns of the current institutions are the payments to the non-ESA capital account that are originated by the part of total income reserved to buy durables. These payments can also be considered as household savings for home production. Finally, the final consumption of home produced goods and services is obtained by adding up intermediate consumption, taxes on products and the household production factor incomes.

In short, non-ESA production is formed of value added generated by factors of household production, intermediate consumption of activities for household production and taxes. Non-ESA supply is composed of non-ESA production of goods and services plus the gross capital formation for household production. Of course, the non-market supply of goods and services must be equal to the demand for goods and services of the household production. 


\section{Classifications in the Extended Social Accounting Matrix}

The classifications used in the ESAM-95 depend on information requirements (see Table 2). Thus, the current accounts for institutional sectors are classified by households, non-profit making organizations, companies and public administration. Households, in turn, are disaggregated into three groups according to tercile breaks of income, the first tercile representing the lowest level of income and the third tercile the highest one. In Table 2 is the marketed income range covered by each tercile. Also a variety of taxes are considered in the current accounts, such as business tax, value added tax and contributions to social security. ${ }^{5}$ Capital accounts for institutions are also accordingly broken down by households, non-profit institutions serving households (NPISH), companies, and public administration, applying the above classification for households. Housing investment by type of household is considered separately from the rest of investment, as we consider it relevant to take different channels for direct savings into account. As for the non-ESA side of the economy, current accounts of households are also classified into three groups, according to an income criterion, although only one account for households in non-market capital accounts is considered.

Regarding the accounts related to factors of production, we follow the recommendations from the Leadership on Social Accounting Matrices (SAM-LEG) of the European Commission and consider different groups of rents, depending on the source. In particular, a distinction between labor income, mixed income (only for market activities) and capital income is outlined. Labor and mixed incomes, in turn, are disaggregated according to educational level and gender. The educational levels considered are the following: less than secondary education, secondary education, and university degree. The classification for labor, together with the detail for households, offers a rich representation of the distribution of the full income in the economy. In Pyatt (1990) a discussion on this typology as opposed to others based on occupational groupings can be found.

The division between the ESA and the non-ESA economy also applies to production activities. These activities in the ESA economy are disaggregated into ten groups, including one for the financial intermediation services indirectly measured (FISIM). For the non-ESA economy we consider a division based on four household production functions. Household production is intended to satisfy basic necessities for

\footnotetext{
${ }^{5}$ Income tax and corporation tax are considered transfers from households and corporations to the public administration.
} 
TABLE 2. Classifications of the ESAM-95

Institutions
Households

Tercile 1 (up to $3,345,529$ pesetas per year)

Tercile 2 (from 3,345529 to 6,253,079 pesetas per year)

NPISH

Tercile 3 (more than $6,253,079$ pesetas per year)

Companies

Government

Labor income and Mixed income

Primary education men

Primary education women

Secondary education men

Secondary education women

Tertiary education men

Tertiary education women

ESA Activities and Commodities I

Agriculture

Industry

Construction

Commerce and repairs

Hotels and restaurants

Transports and communications

Financial intermediation

Real estate, renting and business activities

Other service activities

\section{Commodities II}

Consumption:

Food, beverages and tobacco

Clothing and footwear

Housing, water, electricity, gas and other fuels

Furnishings, household equipment and routine maintenance of the house

Health

Transport

Leisure, entertainment and culture

Education

Hotels, cafes y restaurants

Miscellaneous goods and services

Social services

Collective services

Gross Capital Formation:

Housing

Other construction

Transport equipment

Other products

Changes in inventories

Non-ESA Activities and Commodities

Providing food

Providing shelter

Providing clothing

Providing care and education 
the members of the family such as provision of food, provision of shelter, provision of clothing and provision of care and education (Varjonen, 1998). These functions are considered in a broad sense. Thus, for instance, the function of provision of food consists of the preparation of meals at home, but also includes the services of washing up all the instruments required for cooking. A common characteristic of all these products is that although all of them could be traded, they are not. We do not consider in our analysis any other category of activities that are clearly non-tradable because they are inalienably personal. These activities are marked by Pyatt as "personal" and include sleeping, relaxing or travelling to work. In our framework the commuting costs are implicitly included in the total wages. However, the time spent by the person accompanying children and elderly members of the family to the doctor is included in the evaluation of the "provision of care" activity.

Commodities I are introduced to distribute the production. An almost perfect correspondence exists between production activities and the classification used for Commodities I, except for the FISIM activity that obviously allocates all its production to financial institutions, and therefore disappears from Commodities I.

The ESAM-95 also considers ten groups of goods and services for consumption, according to the international classification COICOP. Nevertheless, some of the consumption of non-profit making organizations and public administrations do not fit into the COICOP classification. For this reason two additional groups are introduced. The group of "collective services" includes all public expenditures that are devoted towards the satisfaction of exclusively collective functions. The last group introduced is called "social services" and includes expenditures on behalf of public institutions and NPISH that are actually household consumption but do not fit in any of the COICOP classifications (e.g. trade union expenditures).

With respect to investment functions, gross capital formation is disaggregated into five groups, which are identical to the ones used in national accounts, that is: housing investment, other construction, transport equipment, machinery equipment and variations in stocks. Finally, looking into the consumption of services for non-market household production, the same four functions of household productions mentioned above are found. 


\section{The estimation of the ESA accounts}

The elaboration of a standard SAM for Spain 1995, which does not include home production, has been explained in detail in Uriel et al. (2004). Here we only comment on the basic sources of information employed there in order to focus on how the non-ESA accounts have been estimated. The general method for the estimation of the standard SAM has been a "top-down" approach. That is, totals are controlled according to national accounts and disaggregated using information from other sources, usually microdata that come from surveys.

The core of the ESA side of the ESAM-95 is the last available Input-Output Framework (IOF-95) of National Accounts for Spain, elaborated according to the ESA95 guidelines. Nevertheless, the information provided by the IOF on the accounts of sectors of activities and products needs to be disaggregated using complementary sources in order to transform products into consumption and investment functions, and to obtain the income of a wide set of productive factors. Moreover, in order to establish the correspondence between the income of factors and the different types of households, information from the European Community Household Panel (ECHP) has been used. Although the ECHP is also the main source of data to estimate transfers from households to other institutional sectors, or within households, other sources of statistical information have also been used (see Uriel et al., 2004, for details). Finally, the distribution of consumption by household type is obtained from the Household Expenditure Survey (HES).

\section{The estimation of the household production accounts}

From a supply point of view, the household production within the ESAM-95 framework is valued at the cost of inputs, with two main components that are represented by means of two matrices: intermediate consumption for home production and the value added generated. As for the demand side, the estimation of home production requires the distribution of household consumption into direct final consumption, intermediate consumption and gross capital formation. To estimate all of these accounts, in addition to the data provided by the IOF, the ECHP and the HES, other information on the allocation of time is required. 


\subsection{The distribution of household consumption}

Family expenditure is classified into three components: direct final consumption, intermediate consumption and household gross capital formation. In addition to this, direct final consumption is disaggregated into consumption of durables and consumption of non-durables. Before assigning expenditure to each of the above categories, a clear definition is needed whereby a decision can be made as to whether the expenditure corresponding to a group of goods and services (according to the HES survey) should be assigned to one of those categories in its entirety or only in part.

Direct final consumption of non-durables consists of goods and services that do not require any transformation at all in order to be consumed. For example, within the consumption group of "food and non-alcoholic beverages" in the HES, bread or mineral water is seen to be assigned $100 \%$ to direct final consumption. Health services are another example. On the other hand, household intermediate consumption consists of those goods requiring some transformation previous to consumption. Raw food such as fish, meat or vegetables that need to be cooked before consumption, are good examples. Household gross capital formation is made up of those goods and services that are purchased to be used in the production process at home for a period longer than one year, such as dishwashers, washing machines or refrigerators.

Above, simple examples have been used to illustrate the differences among consumption categories. However, they are the exception to the general rule by which we need to establish the part of a specific good or service to be allocated to each category. Thus, for example, expenditures in the COICOP category "housing, water, electricity, gas, etc", should be distributed both into intermediate consumption and final consumption of non-durables. Furthermore, expenditure on new cars should be distributed between final consumption of durables and gross capital formation. Then, the imputation of expenditures to each category has been carried out in a first step.

\subsection{Fixed capital consumption in household production}

Fixed capital consumption, which is a part of the value added of home production, captures the cost that households incur through the use of durable goods in home production, due to depreciation. The procedure used to estimate household fixed capital consumption is the permanent inventory method, which consists of the application of the following steps to Spanish data for 1995: (i) collection of the series of durable goods; (ii) calculation of the capital stock; and (iii) estimation of fixed capital consumption. The stock of capital depends on previous investments. We can derive capital stock series without knowing initial stocks by assuming that the assets disappear 
after a sufficiently long period of time. Consequently, given that the maximum life of durable goods has been established at 15 years, we need a series of acquisitions from 1980 onwards.

Spanish National Accounts (CNE-95), which follow the ESA-95, use the COICOP classification for grouping consumption goods. However, the COICOP groups into which durables fit actually include a mixture of goods and services, some of which are non-durable. Moreover, the COICOP classification does not allow us to distinguish, on the one hand, between durable goods used for household production and those used for leisure, which should no longer be considered as an input of home production (a TV for instance), and, on the other hand, among durable goods with different life-spans. Thus, to obtain the desired disaggregated series of durable goods employed in home production, an exploitation of the structural Household Expenditure Survey for the years 1980 and 1990 and the Continuous Household Expenditure Survey (CHES), with quarterly data from 1985 to 1995 , up to the most detailed level by product, has been performed. Interpolation according to CNE-95, for years in which there is no possibility of deriving direct information from HES or CHES, has been necessary.

The series of different durable goods were finally transformed to constant prices, assuming that the price indices for each group or subgroup in consumption, according to the Consumer Price Index, applies to each product inside the group. Once the relevant variables have been identified, the next step is to calculate the stock of capital (SC) available for home production, according to the permanent inventory procedure with linear depreciation. The stock of capital is then obtained from the following expression.

$$
S C_{t, i}=\sum_{h=0}^{U L_{i}-1} G F C F_{t-h, i}\left(1-\frac{h+0.5}{U L_{i}}\right)
$$

where: $G F C F_{t, i}$ is the gross capital formation at constant prices of $\operatorname{good} i$ in period $t$ (purchasing of durables), and $U L_{i}$ the life-span of good $i$ (maximum 15 years).

Finally, the calculus of fixed capital consumption $(F C C)$ for period $t$ of good $i$ is obtained from:

$$
F C C_{t, i}=G F C F_{t, i}\left(\frac{0.5}{U L_{i}}\right)+\sum_{h=1}^{U L_{i}-1} G F C F_{t-h, i}\left(\frac{1}{U L_{i}}\right)+G F C F_{t-U L_{i}, i}\left(\frac{0.5}{U L_{i}}\right)
$$




\subsection{Estimation of the value added of household production}

The gross value added of household production is obtained by adding up the following components: housework, household fixed capital consumption and net taxes on production. Household fixed capital consumption was obtained in the previous section. Net taxes on production are those associated with intermediate consumption for home production. They are obtained by function of household production and disaggregated by sector. In this subsection we focus on how the estimation of unpaid household work is addressed.

In order to obtain the monetary value of housework for Spain in 1995, an imputation approach assigning wages of substitute household workers is used. Broadly speaking, the market wages of domestic workers (net of taxes) are applied to the hours spent on household tasks by the Spanish population in 1995. According to GoldschmidtClermont (1993), these are the most satisfactory wages for performing a wage-based valuation of households' productive time. A classification of functions of household production broken down by gender and educational level has been used. We have proceeded according to the following five steps.

Step 1 involves the estimation of average unpaid hours spent in household production. To estimate working time at home we use data from a survey on the use of time provided by the Spanish Women's Institute (Instituto de la Mujer). Table 3 offers the annual average number of hours time spent in the four main functions of providing food, shelter, clothing and care (distinguishing between women and men and between educational levels).

TABLE 3. Average time dedicated to household production in annual terms (1996, hours)

\begin{tabular}{|c|c|c|c|c|c|c|}
\hline & & \multicolumn{4}{|c|}{ Functions of household production } & \multirow[b]{2}{*}{ Total } \\
\hline & & $\begin{array}{l}\text { Providing } \\
\quad \text { food }\end{array}$ & $\begin{array}{l}\text { Providing } \\
\text { shelter }\end{array}$ & $\begin{array}{l}\text { Providing } \\
\text { clothing }\end{array}$ & \begin{tabular}{|} 
Providing care \\
and education
\end{tabular} & \\
\hline \multirow{2}{*}{ Primary education } & Men & 107.1 & 118.4 & 6.9 & 258.3 & 490.8 \\
\hline & Women & 862.7 & 445.8 & 350.4 & 322.2 & $1,981.0$ \\
\hline \multirow{2}{*}{ Secondary education } & Men & 94.5 & 144.7 & 2.7 & 183.2 & 425.1 \\
\hline & Women & 454.2 & 304.5 & 169.6 & 352.4 & $1,280.8$ \\
\hline \multirow{2}{*}{ University education } & Men & 96.5 & 171.1 & 2.5 & 148.4 & 418.5 \\
\hline & Women & 403.0 & 243.8 & 69.7 & 204.4 & 920.8 \\
\hline \multirow{2}{*}{ Total } & Men & 298.1 & 434.2 & 12.1 & 589.9 & 1334.3 \\
\hline & Women & 1719.9 & 994.1 & 589.7 & 879 & 4182.7 \\
\hline
\end{tabular}


It is important to note that, as Table 3 shows, on average, women of all educational levels spend more than double the time spent by men on household tasks, which is a kind of stylized fact of household production (see Goldschmidt-Clermont \& Pagnossin-Aligisakis, 1999). However, the lower the level of education is, the more the difference grows. Participation of women in relation to men also varies by function. Comparing the tasks of cooking and caring, women of middle and upper educational levels are found to spend on average more than five times the time spent by men on these tasks, while less than double the time is spent on caring and education.

Step 2 covers the estimation of total unpaid hours worked in household production. To obtain hours worked at home, we first estimate the distribution of the Spanish population over 18, by educational level, using the Spanish Labor Force Survey 1995 (EPA), given that the survey on the use of time refers to this age group. Furthermore, in order to obtain meaningful comparisons between paid and unpaid work, we need to take this age group as the minimum statutory working age. The average number of hours spent by women and men in different functions is then applied to the population over 18, in order to calculate the total number of hours used in household production. As Table 4 shows, overall, the female share in total working hours for household production is $79 \%$. This percentage ranges from $61.3 \%$ in childcare provision to $99 \%$ in the function of providing clothing.

TABLE 4. Total time dedicated to household production (millions of hours in annual terms)

\begin{tabular}{|l|l|r|r|r|r|r|}
\cline { 3 - 6 } \multicolumn{2}{c|}{} & \multicolumn{4}{c|}{ Functions of household production } & \multicolumn{1}{c|}{} \\
\cline { 3 - 6 } \multicolumn{2}{c|}{} & $\begin{array}{c}\text { Providing } \\
\text { food }\end{array}$ & $\begin{array}{c}\text { Providing } \\
\text { shelter }\end{array}$ & $\begin{array}{c}\text { Providing } \\
\text { clothing }\end{array}$ & $\begin{array}{c}\text { Providing } \\
\text { care and } \\
\text { education }\end{array}$ & Total \\
\hline \multirow{2}{*}{ Primary education } & Men & $7,856.3$ & $4,059.4$ & $3,190.6$ & $2,933.9$ & $18,040.1$ \\
& Women & 794.9 & 879.1 & 51.3 & $1,917.7$ & $3,643.1$ \\
\hline Secondary education & Men & $2,396.6$ & $1,606.7$ & 895.0 & $1,859.2$ & $6,757.6$ \\
& Women & 556.0 & 851.0 & 15.9 & $1,077.6$ & $2,500.5$ \\
\hline \multirow{2}{*}{ University education } & Men & 584.2 & 353.4 & 101.1 & 296.3 & $1,335.0$ \\
& Women & 134.1 & 237.7 & 3.4 & 206.2 & 581.4 \\
\hline \multirow{2}{*}{ Total } & Men & $10,837.1$ & $6,019.6$ & $4,186.6$ & $5,089.4$ & $26,132.7$ \\
& Women & $1,485.0$ & $1,967.8$ & 70.7 & $3,201.6$ & $6,725.0$ \\
\hline
\end{tabular}


Step 3 determines the number of full-time equivalent jobs in household production. According to the legal regulation provided by the Spanish Worker's Statute, the maximum number of yearly working hours has been set at 1,826. Now, if the hours worked in household production are divided by the legal maximum number of working hours per year, the number of full-time equivalent posts in household production is obtained. As Table 5 shows, there are approximately 14 million full-time equivalent posts in household production that correspond to women and only 3.5 million that correspond to men. Comparing our estimation of non-ESA production in Spain in 1995 with the ESA production we find that the number of full-time equivalent jobs potentially generated by household production is much higher than the number of jobs generated in the labor market (which amounts to approximately 13 million). It is interesting to note that, given the actual distribution of unpaid working hours, the household chores that potentially generate more full-time equivalent jobs for women are connected to food provision. For men, however, this is the case with care and education provision, albeit to a considerably lesser extent.

TABLE 5. Equivalent full-time jobs (thousands of jobs)

\begin{tabular}{|c|c|c|c|c|c|c|}
\hline & & \multicolumn{4}{|c|}{ Functions of household production } & \multirow[b]{2}{*}{ Total } \\
\hline & & $\begin{array}{l}\text { Providing } \\
\quad \text { food }\end{array}$ & $\begin{array}{l}\text { Providing } \\
\text { shelter }\end{array}$ & $\begin{array}{l}\text { Providing } \\
\text { clothing }\end{array}$ & $\begin{array}{l}\text { Providing } \\
\text { care and } \\
\text { education }\end{array}$ & \\
\hline \multirow{2}{*}{ Primary education } & Men & $4,302.4$ & $2,223.1$ & $1,747.3$ & $1,606.7$ & $9,879.6$ \\
\hline & Women & 435.3 & 481.4 & 28.1 & $1,050.2$ & $1,995.1$ \\
\hline \multirow{2}{*}{ Secondary education } & Men & $1,312.5$ & 879.9 & 490.1 & $1,018.2$ & $3,700.8$ \\
\hline & Women & 304.5 & 466.0 & 8.7 & 590.2 & $1,369.4$ \\
\hline \multirow{2}{*}{ University education } & Men & 319.9 & 193.6 & 55.3 & 162.3 & 731.1 \\
\hline & Women & & 130.2 & 1.9 & 112.9 & 318.4 \\
\hline \multirow{2}{*}{ Total } & Men & $5,934.9$ & $3,296.6$ & $2,292.8$ & $2,787.2$ & $14,311.4$ \\
\hline & Women & 813.3 & $1,077.7$ & 38.7 & $1,753.3$ & $3,682.9$ \\
\hline
\end{tabular}

Step 4 deals with the estimation of yearly net wage of a paid job in the domestic service sector. The data to estimate the yearly net wage of a market full-time equivalent domestic service job are obtained from the primary input matrix of the IOF-95, corresponding to the sector of domestic services with wage earners. Given that unpaid work does not pay social security contributions, we then proceed to estimate the net wage of domestic workers after social security contributions. Taking into account that total social security contributions paid by the employers and employees were $18.3 \%$ and $3.7 \%$ of gross wages respectively we use the ratio $3.7 / 18.3$ to obtain an estimation for the social security contributions paid by employees from the figure of 17,263 million 
pesetas in the national accounts. Thus, as Table 6 shows, we estimate that total net wages amount to 729,522 million pesetas (1995 prices).

TABLE 6. Household services in the IOF 95 (millions of pesetas)

\begin{tabular}{|l|r|}
\hline \multicolumn{1}{|c|}{ Concept } & \multicolumn{1}{c|}{$\begin{array}{c}\text { Household } \\
\text { services }\end{array}$} \\
\hline Salaried workers remuneration & 750,275 \\
Employers' social contributions & 17,263 \\
Salary and wages before tax & 733,012 \\
Employees' social contributions (estimation) & 3,490 \\
Wages and net salaries (estimation) & 729,522 \\
Gross added value in basic prices & 750,275 \\
Output at basic prices & 750,275 \\
\hline Jobs & 632.6 \\
\hline Full-time jobs & 418.9 \\
\hline Annual net average salary for full-time household service (millions of pesetas) & $1,741,517.5$ \\
\hline
\end{tabular}

The full time equivalent posts corresponding to domestic workers can also be obtained from the IOF-95. Thus, dividing the estimate of total net wages by the total number of full-time equivalent posts provided by the IOF-95, the average yearly wage of a full-time equivalent domestic service job is obtained, which amounted to nearly two million pesetas.

Step 5 determines the value of unpaid household work by multiplying the average yearly wage of full-time equivalent domestic workers by the number of fulltime equivalent jobs in household production. The method used to estimate imputed values is also subject to criticism. ${ }^{6}$ For instance, one could argue that housework is overvalued by using the going wage of domestic service because it is only those for whom the opportunity cost of do-it-yourself activities is less than the cost of hiring help that do their own housework. This criticism assumes a perfect labor market, and can be mitigated once flaws in the labor market are taken into account. In particular, Pyatt (1990) points out two aspects to bear in mind. The first is related to transaction costs and the second refers to the fact that not all individuals are free to allocate their time across different activities in continuously variable amounts. Given that diverse imperfections in the labor market do exist, the estimation of housework could even be conservative in some cases, because the wage for domestic workers was applied to all

\footnotetext{
6 For a discussion of valuation issues arising in estimating the value of labor services in household production see Goldschmidt-Clermont (1993) and also Landefeld \& McCulla (2000).
} 
working hours, regardless of the qualifications required for each specific task. However, the wage for a general worker or housekeeper is one of the lowest in the entire Spanish labor market.

Table 7 shows that the value of unpaid household work provided by women in Spain in 1995 was 24.9 trillion pesetas in comparison to only 6.4 trillion pesetas provided by men. According to Spanish National Accounts, the Gross Domestic Product (GDP) amounted to 72.8 trillion pesetas in 1995. Consequently, the value of unpaid household work provided by both women and men in Spain was approximately $43 \%$ of GDP in 1995. This figure is in line with the estimates for different countries provided by Goldschimdt-Clermont \& Pagnossin-Aligisakis (1999). However, for the United States, Landefeld \& McCulla (2000) estimates that the inclusion of household production would increase the GDP by $50 \%$ in 1946 and by $36 \%$ in 1992 . According to these figures the importance of unpaid labor at home is in the 1990s considerably higher in Spain than in the US, indicating perhaps a narrower gap in economic activity than the official GDP measures reflect. Moreover, there is a different behaviour on behalf of women and men for the non-ESA side, and the opposite occurs in the ESA part of the Spanish economy. The male share in the value of paid work is $72.23 \%$, but only $20.46 \%$ in the estimated value of housework, as Table 7 shows. This fact actually introduces an important gender bias in the standard measures of the contribution of women to aggregate welfare.

TABLE 7. Household production work value (billions of pesetas)

\begin{tabular}{|c|c|c|c|c|c|c|}
\hline & & \multicolumn{4}{|c|}{ Households production functions } & \multirow[b]{2}{*}{ Total } \\
\hline & & $\begin{array}{l}\text { Providing } \\
\text { food }\end{array}$ & $\begin{array}{l}\text { Providing } \\
\text { shelter }\end{array}$ & $\begin{array}{l}\text { Providing } \\
\text { clothing }\end{array}$ & $\begin{array}{l}\text { Providing care } \\
\text { and education }\end{array}$ & \\
\hline & \multirow{2}{*}{$\begin{array}{l}\text { Men } \\
\text { Women }\end{array}$} & 758.2 & 838.4 & 48.9 & $1,829.0$ & $3,474.6$ \\
\hline & & $7,492.8$ & $3,871.6$ & $3,042.9$ & $2,798.1$ & $17,205.5$ \\
\hline \multirow{2}{*}{$\begin{array}{l}\text { Secondary } \\
\text { education }\end{array}$} & Men & 530.3 & 811.6 & 15.2 & $1,027.8$ & $2,384.8$ \\
\hline & Women & $2,285.8$ & $1,532.4$ & 853.6 & $1,773.2$ & $6,445.0$ \\
\hline \multirow{2}{*}{$\begin{array}{l}\text { University } \\
\text { education }\end{array}$} & Men & 127.9 & 226.7 & 3.3 & 196.7 & 554.5 \\
\hline & Women & 557.1 & 337.1 & 96.4 & 282.6 & $1,273.2$ \\
\hline \multirow{3}{*}{ Totals } & Men & $1,416.3$ & $1,876.8$ & 67.4 & $3,053.5$ & $6,413.9$ \\
\hline & Women & $10,335.7$ & $5,741.1$ & $3,992.9$ & $4,853.9$ & $24,923.6$ \\
\hline & Both sexes & $11,752.0$ & $7,617.8$ & $4,060.3$ & $7,907.4$ & $31,337.5$ \\
\hline
\end{tabular}




\subsection{Intermediate consumption}

To fit intermediate consumption into the ESAM it is necessary to disaggregate it by domestic production function and products. Table 8 contains both intermediate consumption and net taxes on goods associated with intermediate consumption. The figures indicate that the weight in intermediate consumption of agricultural products is only significant in the function of providing food at home, that real estate and renting are the main components in the intermediates needed to provide shelter, and that industrial products are, in general, the most demanded intermediate products for household production.

TABLE 8. Intermediate consumption (billions of pesetas)

\begin{tabular}{|c|c|c|c|c|c|}
\hline & $\begin{array}{l}\text { Providing } \\
\text { food }\end{array}$ & $\begin{array}{l}\text { Providing } \\
\text { shelter }\end{array}$ & $\begin{array}{l}\text { Providing } \\
\text { clothing }\end{array}$ & $\begin{array}{l}\text { Providing care } \\
\text { and education }\end{array}$ & $\begin{array}{c}\text { Total } \\
\text { intermediate } \\
\text { consumption }\end{array}$ \\
\hline Agriculture & 364.2 & 1.0 & 0.4 & 1.0 & 366.6 \\
\hline Industry & $2,146.0$ & 222.2 & 123.3 & 301.8 & $2,793.3$ \\
\hline Construction & 27.2 & 17.0 & 7.5 & 16.9 & 68.6 \\
\hline Commerce and repairs & $1,300.8$ & 115.4 & 75.5 & 223.5 & $1,715.3$ \\
\hline Hotel trade & 0.0 & 0.0 & 0.0 & 0.0 & 0.1 \\
\hline Transports and communications & 182.0 & 29.7 & 20.5 & 88.8 & 321.1 \\
\hline Financial intermediation & 11.9 & 16.8 & 4.0 & 9.0 & 41.7 \\
\hline $\begin{array}{l}\text { Real estate, renting and business } \\
\text { services }\end{array}$ & 410.1 & 255.5 & 113.0 & 254.9 & $1,033.5$ \\
\hline Other services & 202.4 & 175.6 & 69.5 & 178.2 & 625.7 \\
\hline Total & $4,644.7$ & 833.3 & 413.7 & $1,074.3$ & $6,966.0$ \\
\hline Net taxes over products & 449.6 & 75.0 & 37.9 & 98.4 & 660.9 \\
\hline $\begin{array}{l}\text { Total (including net taxes } \\
\text { over products) }\end{array}$ & $5,094.3$ & 908.3 & 451.7 & $1,172.7$ & $7,627.0$ \\
\hline
\end{tabular}

\subsection{The value of household production}

The value of household production is obtained by adding up the value of unpaid work at home, net taxes on products, consumption of fixed capital and intermediate consumption, whereby the sum of the first three factors is the value added of household production. The value of household production appears in Table 9, classified by function of household production. Note that most of the value of household production 
is value added (82.7\%), the remaining $17.3 \%$ being intermediate consumption. Similarly, housework contributes $94.1 \%$ to the value added of household production; fixed capital consumption represents only $3.9 \%$ and the remaining $2 \%$ are net taxes on goods associated to intermediate consumption. The function of providing food represents $38 \%$ of the total value added of household production followed closely by care provision with $25.4 \%$.

TABLE 9. Value of household production (billions of pesetas)

\begin{tabular}{|l|r|r|r|r|r|}
\cline { 2 - 6 } \multicolumn{1}{c|}{} & \multicolumn{1}{c|}{$\begin{array}{c}\text { Providing } \\
\text { food }\end{array}$} & \multicolumn{1}{c|}{$\begin{array}{c}\text { Providing } \\
\text { shelter }\end{array}$} & \multicolumn{1}{c|}{$\begin{array}{c}\text { Providing } \\
\text { clothing }\end{array}$} & $\begin{array}{c}\text { Providing care } \\
\text { and education }\end{array}$ & \multicolumn{1}{|c|}{ Total } \\
\hline $\begin{array}{l}\text { Value of non- } \\
\text { remunerated } \\
\text { household work } \\
\begin{array}{l}\text { Fixed capital } \\
\text { consumption }\end{array}\end{array}$ & $11,752.0$ & $7,617.8$ & $4,060.3$ & $7,907.4$ & $31,337.5$ \\
Product net taxes & 484.9 & 219.3 & 146.3 & 445.6 & $1,296.1$ \\
\hline Gross added value & $12,686.5$ & 74.6 & 37.9 & 98.4 & 660.9 \\
\hline $\begin{array}{l}\text { Intermediate } \\
\text { consumption }\end{array}$ & $4,644.7$ & 83.9 & $4,244.6$ & $8,451.4$ & $33,294.5$ \\
$\begin{array}{l}\text { Household } \\
\text { production values }\end{array}$ & $17,331.2$ & $8,745.4$ & 413.7 & $1,074.3$ & $6,966.0$ \\
\hline
\end{tabular}

\subsection{Distribution of the factor labor in household production}

The value of household unpaid work obtained in Section 5.3 is distributed among the households classified into three groups according to the distribution of income. To do so we follow a similar procedure, with the following steps: (a) estimation of average hours devoted to household production, by income-tercile, educational level and gender; (b) estimation of the population older than 18, by income-tercile, educational level and gender; (c) total time devoted to household production, classified by income-tercile, educational level and gender; (d) full time equivalent jobs in household production; (e) total value of household unpaid work, classified by educational level and gender accruing to families. The result is shown in Table 10. This table offers an immediate but interesting conclusion because the column with totals clearly shows that the initial market distribution of income is greatly affected once the imputation of labor income is taken into account, given that the imputed income varies 
inversely with the market income. This result is also present in Bonke (1992) and Jenkins \& O’Leary (1996).

TABLE 10. Distribution of the factor labor for household production

\begin{tabular}{|l|r|r|r|r|r|r|r|}
\hline & \multicolumn{1}{|c|}{$\begin{array}{c}\text { Primary } \\
\text { education } \\
\text { men }\end{array}$} & \multicolumn{1}{c|}{$\begin{array}{c}\text { Primary } \\
\text { education } \\
\text { women }\end{array}$} & $\begin{array}{c}\text { Secondary } \\
\text { education } \\
\text { men }\end{array}$ & $\begin{array}{c}\text { Secondary } \\
\text { education } \\
\text { women }\end{array}$ & $\begin{array}{r}\text { University } \\
\text { education } \\
\text { men }\end{array}$ & $\begin{array}{c}\text { University } \\
\text { education } \\
\text { women }\end{array}$ & Total \\
\hline Tercile 1 & $2,511.1$ & $8,595.5$ & 494.7 & $1,586.4$ & 24.6 & 101.9 & $13,314.2$ \\
Tercile 2 & 380.9 & $3,593.2$ & $1,318.4$ & $3,432.7$ & 95.9 & 282.7 & $9,103.8$ \\
Tercile 3 & 582.5 & $5,016.8$ & 571.7 & $1,425.9$ & 434.1 & 888.6 & $8,919.6$ \\
Total & $3,474.6$ & $17,205.5$ & $2,384.8$ & $6,445.0$ & 554.5 & $1,273.2$ & $31,337.6$ \\
\hline
\end{tabular}

\subsection{The distribution of consumption for the non-ESA households}

All household production is consumed by families. To obtain the consumption we estimate how the value of such production classified by the four housework production functions is distributed among the three groups of families. The result is displayed in Table 11. It indicates that the richer the household, the less important (in relative terms) the activity of providing care and education, and the more important the activity of providing food.

\section{TABLE 11. Distribution of non-ESA consumption}

\begin{tabular}{|l|r|r|r|r|}
\hline & \multicolumn{1}{|c|}{ Tercile 1 } & \multicolumn{1}{c|}{ Tercile 2 } & \multicolumn{1}{c|}{ Tercile 3 } & \multicolumn{1}{c|}{ Total } \\
\hline Providing food & $5,831.2$ & $5,080.3$ & $6,419.8$ & $17,331.3$ \\
Providing shelter & $3,401.3$ & $2,545.6$ & $2,798.4$ & $8,745.4$ \\
Providing clothing & $1,811.3$ & $1,354.9$ & $1,492.1$ & $4,658.3$ \\
Providing care and education & $3,591.1$ & $2,770.0$ & $3,164.5$ & $9,525.6$ \\
Total & $\mathbf{1 4 , 6 3 4 . 9}$ & $\mathbf{1 1 , 7 5 0 . 8}$ & $\mathbf{1 3 , 8 7 4 . 8}$ & $\mathbf{4 0 , 2 6 0 . 6}$ \\
\hline
\end{tabular}




\section{The ESAM-95: Aggregate estimates}

Table 12 displays the estimated flows of the ESAM-95 in a very summarized version. $^{7}$ The equality between totals by rows and columns, reflecting the consistent connection of household production and market production, should be noted. The ESAM-95 encompasses the usual measurements of household production, such as the labor valuation of household production, but also other new concepts, such as the extended private consumption introduced in Goldschmidt-Clermont \& PagnossinAligisakis (1999).

In the first column, called ESA households, the transfers between the ESA and non-ESA part of the households appears, amounting to 8,767. In a conventional SAM this amount would be included in final consumption, but now it reflects the value of intermediate goods and durables necessary to carry out the household production. The part of this expenditure going to durables is captured in the second column called HP households and amounts to 1,140 gross of taxes. The part allocated to purchasing intermediate goods is displayed in the column Non-ESA Activities and amounts to 6,966 net of taxes and 661 paid in the form of indirect taxes. Also from the 1,140 billion pesetas paid for purchasing durables, 99 billion go to taxes as is shown in the column Non-ESA Commodities II.

The imputed value of work at home $(31,337)$ and the consumption of fixed capital $(1,296)$ are paid by Non-ESA activities and returned to the household in the columns called HP Labor Factor and HP capital factor. Together with the transfers received by the ESA part of the economy, they determine the consumption of the services produced at home $(40,261)$ in the second column.

\footnotetext{
${ }^{7}$ The detailed table appears in the annex A1.
} 
TABLE 12. Aggregated ESAM-95

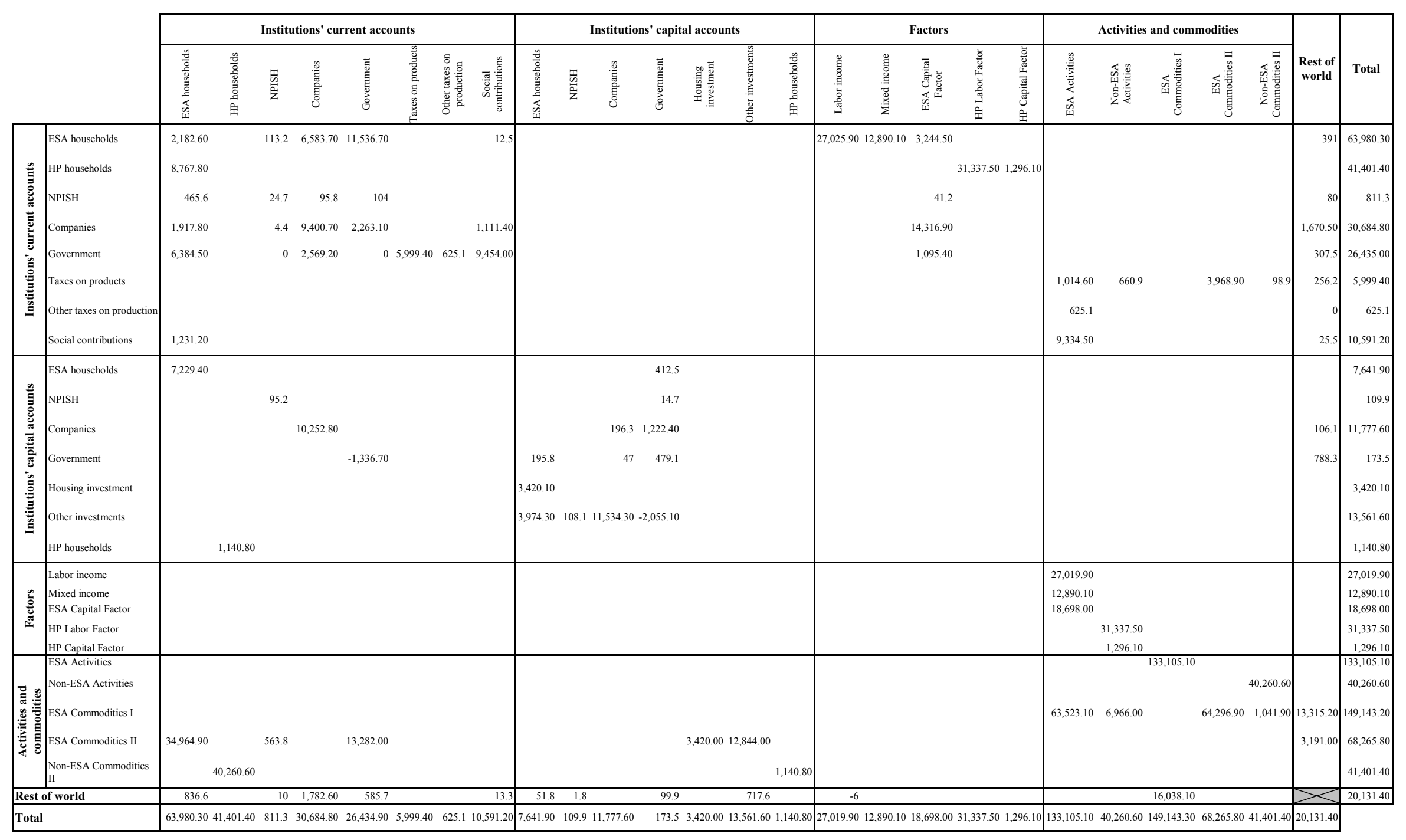




\section{Concluding remarks}

This research has implemented a methodology for integrating household production accounts into a social accounting framework. The procedure for estimating the components of the non-ESA part was made following the rules applied to the ESA part. The new flow of income is fully consistent with the market side of the economy and provides information to ascertain in some detail a part of the economy not accounted for in the national accounting system. The estimated flows obtained in this paper confirm the important volume of non-ESA production in the Spanish economy.

Recently, Apps (2004) called for a modelling approach that fully integrates the economics of household production. The incorporation of household production into the economic analysis at both levels, theoretically and empirically, is fundamental for the study of a variety of issues, including the intra-household allocation of resources and the distribution of real income, the real household living standards and the effects of changes in policy variables. In that sense, an extended SAM with household production, such as the one introduced here, can be used as benchmark information for computable general equilibrium (CGE) models in which the distribution of time between market and non-market activities matters. Some examples of applications to economic policy would include the following.

First, development policy. Household production in underdeveloped countries is of a sizeable weight and social accounting matrices have proved there to be a useful tool for modelling (see Round, 2003), either by obtaining multipliers directly from the table or as the benchmark for computable general equilibrium models. An example of the latter is provided by Fontana \& Wood (2000), who analyze the effects of trade using a CGE model calibrated to a compacted social accounting matrix extended to consider household production. Second, environmental policy, by including intermediate inputs in household production that contaminate with different intensities (an idea that is developed in Pfaff et al., 2004) and tackling the implications of policies to reduce the amounts of pollution as in Babiker et al. (2003). Third, tax policy in a general equilibrium context, by taking account of the fact that the welfare impact of taxes depends on how different households combine unpaid work and goods to produce goods and services (see Pigott \& Whalley, 2001; Iorwerth \& Whalley, 2002; Kleven, 2004; and Apps \& Rees, 2004), and allowing both efficiency and equity effects. 


\section{References}

Apps, P. (2004) Gender, Time Use, and Models of the Household, The World Bank, Policy Research Working Paper Series: 3233 (Washington, DC: World Bank).

Apps, P. \& Rees, R. (2004) The household, time use and tax policy, Cesifo Economic Studies, 50, pp. 479-500.

Babiker, M.H., Metcalf, G.E. \& Reilly, J. (2003) Tax distortions and global climate policy, Journal of Environmental Economics and Management, 46, pp. 269-287.

Becker, G. (1965) A theory of the allocation of time, Economic Journal, 75, pp. 493-517.

Bonke, J. (1992) Distribution of economic resources: implications of including household production, Review of Income and Wealth, 38, pp. 281-293.

Bos, F., Hollanders, H. \& Keuning, S.J. (1994) A research and development module supplementing the national accounts, Review of Income and Wealth, 40, pp. 273-286.

Chadeau, A \& Roy, C. (1986) Relating households' final consumption to household activities: substitutability or complementarity between market and non-market production, Review of Income and Wealth, 32, pp. 387-407.

de Haan, M. \& Keuning, S.J. (1996) Taking the environment into account: the NAMEA approach, Review of Income and Wealth, 42, pp. 131-148.

EUROSTAT (1995) European System of Account (ESA-95).

Fontana, M. \& Wood, A. (2000) Modelling the effects of trade on women, at work and at home, World Development, 28, pp. 1173-1190.

Goldschmidt-Clermont, L. (1993) Monetary valuation of non-market productive time methodological considerations, Review of Income and Wealth, 39, pp. 419-433.

Goldschmidt-Clermont, L. \& Pagnosin-Aligisakis, E. (1999) Households' non-SNA production: labor time, value of labor and of product, and contribution to extended private consumption, Review of Income and Wealth, 45, pp. 519-529.

Gronau, R. (1977) Leisure, home production and work-the theory of the allocation of time revisited, Journal of Political Economy, 85, pp. 1099-1123.

Gronau, R. (1997) The theory of home production - the past ten years, Journal of Labor Economics, 15, pp. 197-205.

Gronau, R. \& Hamermesh, D.S. (2003) Time vs. Goods: the Value of Measuring Household Production Technologies, NBER Working Paper Series, 9650 (Cambridge, MA: National Bureau of Economic Research).

Holloway, S., Short, S. \& Tampling, S. (2002) Household Satellite Account (Experimental) Methodology (London: National Statistics). 
Iorwerth, A. \& Whalley, J. (2002) Efficiency considerations and the exemption of food from sales and value added taxes, Canadian Journal of Economics, 35, pp. 167-182.

Jenkins, S.P. \& O'Leary, N.C. (1996) Household income plus household production: the distribution of extended income in the U.K., Review of Income and Wealth, 42, pp. 401419.

Jorgenson, D.W. \& Fraumeni, B.M. (1989) The accumulation of human and non-human capital, 1948-84, in: R. Lipsey \& H. Tice (Eds) The Measurement of Savings, Investment, and Wealth, pp. 227-285 (Chicago: University of Chicago Press).

Keuning, S. (1998) Interaction between national accounts and socio-economic policy, Review of Income and Wealth, 44, pp. 345-359.

Kleven, H.J. (2004) Optimal taxation and the allocation of time, Journal of Public Economics, 88 , pp. 545-557.

Landefeld, J.S. \& McCulla, S.H. (2000) Accounting for nonmarket household production within a national accounts framework, Review of Income and Wealth, 46, pp. 289-307.

Lützel, H. (1989) Household production and national accounts, Statistical Journal of the United Nations, ECE 6, pp. 337-348.

OECD, International Monetary Fund, ILO \& CIS-STAT (2002) Measuring the Non-Observed Economy: a Handbook (Paris: OECD).

Pfaff, A., Chaudhuri, S. \& Nye, H. (2004) Household production and environmental Kuznets curves, Environmental and Resource Economics, 27, pp. 187-200.

Piggott, J. \& Whalley, J. (2001) VAT base broadening, self supply, and the informal sector, American Economic Review, 91, pp. 1084-1094.

Pyatt, G. (1985) Commodity Balances and National Accounts: A SAM Perspective, Review of Income and Wealth, 31, pp. 155-169.

Pyatt, G. (1990) Accounting for time use, Review of Income and Wealth, 36, pp. 33-52.

Robinson, S., Cattaneo, A. \& El-Said, M. (2001) Updating and estimating a social accounting matrix using cross entropy methods, Economic Systems Research, 13, pp. 47-64.

Round, J.I. (2003) Constructing SAMs for development policy analysis: lessons learned and challenges ahead, Economic Systems Research, 15, pp. 161-183.

United Nations, EUROSTAT, IMF, OECD and World Bank (1993): System of National Accounts 1993.

Uriel, E., Ferri, J. \& Molto. M.L. (2004) Estimación de una matriz de contabilidad social de 1995 para España (MCS-95), Revista Estadística Española, forthcoming.

van de Ven, P., Kazemier, B. \& Keuning, S. (1999) Measuring Well-being with an Integrated System of Economic and Social Accounts (Voorburg: Statistics Netherlands, Division Presentation and Integration). 
Varjonen, J. (1998) Methodology for a Satellite Account of Household Production, International Statistical Seminars, No. 38 (San Sebastian: EUSTAT - The Basque Statistics Institute). 